\title{
EFFECT OF THE CARBONIZATION TEMPERATURE OF PLANT BIOMASS ON THE STRUCTURE, SURFACE CONDITION AND ELECTRICAL CONDUCTIVE PROPERTIES OF CARBON NANOPOROUS MATERIAL
}

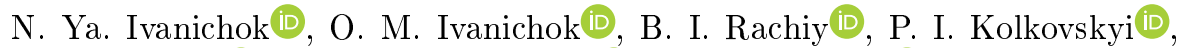

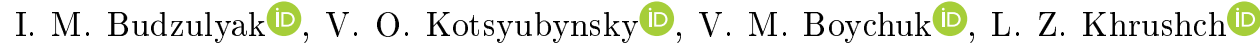 \\ Vasyl Stefanyk Precarpathian National University, \\ 57, Shevchenko St., Ivano-Frankivsk, UA-76000, Ukraine \\ e-mails: bogdan.rachiy@pnu.edu.ua, lesya.khrushch@pnu.edu.ua
}

(Received 04 June 2021; in final form 22 July 2021; accepted 19 August 2021; published online 01 October 2021)

\begin{abstract}
In this work, we have obtained a nanoporous carbon material (CM) from walnut shells using the method of thermal carbonization. Moreover, the influence of the carbonization temperature of the raw material on the electrical conductivity of the CM obtained by Raman, infrared (IR), and impedance spectroscopy has been investigated. Consequently, to analyze the evolution of the electrical conductivity of the material with an increase in the carbonization temperature, the theory of percolation has been applied.
\end{abstract}

Key words: carbon nanoporous material, electrical conductivity, impedance spectroscopy, Raman spectroscopy, IR spectroscopy.

DOI: https://doi.org/10.30970/jps.25.3801

\section{INTRODUCTION}

The rapid growth in the consumption of fossil fuels is initiating the search for options for the use of renewable energy sources (wind power and solar energy). However, the critical dependence of the efficiency of renewable energy sources on uncontrollable factors necessitates the development of a new generation of energy storage devices [1]. Promising in this regard is the use of electrochemical capacitor (EC) technology, which is characterized by a high specific power, a fast charge / discharge process and stability during the cycling of EC $[2,3]$. However, compared to lithium ion batteries, such systems have low values of specific energy, which significantly limits their use [4]. As a result, a significant amount of research focuses on the development and improvement of electrode materials for electrochemical capacitors to increase their specific capacity and energy $[5,6]$. Particular attention is paid to the research on porous carbon materials that have a controlled structure and pore size distribution, a high surface area and technologically low standing. To obtain porous carbon materials, available raw materials of natural plant origin are most often used $[7,8]$.
The aim of this research is to optimize the method of obtaining a nanoporous carbon material and to establish the relationship between the carbonization temperature of plant biomass (walnut shells) and the electrophysical properties of the obtained CM.

\section{EXPERIMENT}

The objects of this research were samples of a CM obtained by thermal carbonization in the temperature range from $400^{\circ} \mathrm{C}$ to $1000^{\circ} \mathrm{C}$ with steps of $100^{\circ} \mathrm{C}$. The walnut shells were used as a raw material. The nut shells, peeled from the kernels, were poured into an autoclave and placed in a furnace, and were heated to a predetermined temperature. The heating rate was $5^{\circ} \mathrm{C} / \mathrm{min}$. Conceptually, the applied methodological approach is close to that described in work [8].

Figure 1 shows the scheme of obtaining the CM. The samples were obtained depending on the carbonization temperature, the symbols of which and the values of the bulk density $d_{0}$ of the obtained materials are given in Table 1.
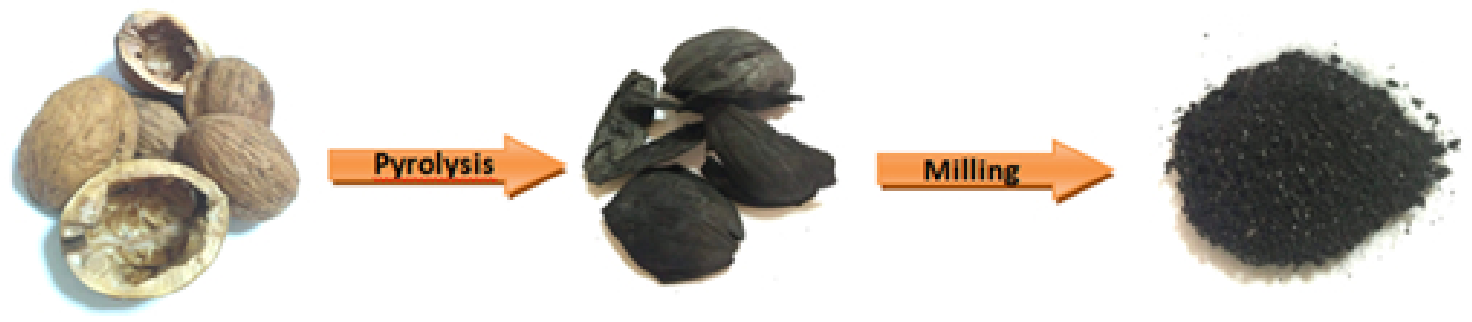

Fig. 1. Schematic illustration of the synthesis of a CM from walnut shells 


\begin{tabular}{|l|c|c|c|c|c|c|c|}
\hline Sample & $\mathrm{C} 1$ & $\mathrm{C} 2$ & $\mathrm{C} 3$ & $\mathrm{C} 4$ & $\mathrm{C} 5$ & $\mathrm{C} 6$ & $\mathrm{C} 7$ \\
\hline Carbonization temperature, ${ }^{\circ} \mathrm{C}$ & 400 & 500 & 600 & 700 & 800 & 900 & 1000 \\
\hline$d_{0}, \mathrm{~g} / \mathrm{cm}^{3}$ & 0.35 & 0.36 & 0.39 & 0.41 & 0.42 & 0.43 & 0.46 \\
\hline
\end{tabular}

Table 1. Parameters of the investigated samples

The Raman spectroscopy was used to identify the different phases of the CM. Spectra were acquired using a Horiba Jobin-Yvon T-64000 triple spectrometer equipped with an Olympus BX41 confocal microscope. The CM samples were irradiated with an $\mathrm{Ar}^{+} / \mathrm{Kr}^{+}$laser (wavelength $488 \mathrm{~nm}$ ) and recorded at room temperature in the backscattering geometry. The accuracy of determining the frequency position of the phonon line was $\leq 0.15 \mathrm{~cm}^{-1}$.

The method of infrared (IR) spectroscopy was used to obtain information about the state of the surface and the presence of functional groups on the surface of the carbonized CM. The IR spectra were obtained in the transmission mode on a Thermo Nicolet Fourier spectrometer (FTIR method).

The method of impedance spectroscopy was used to establish the regularities of the change in electrical conductivity from the carbonization temperature of the obtained CM. The measurements were carried out using an AUTOLAB PGSTAT100 complex "ECO CHEMIE", (Netherlands). Measurements of the real $Z^{\prime}$ and imaginary $Z^{\prime \prime}$ parts of the complex resistance $\left(Z=Z^{\prime}-j Z^{\prime \prime}\right.$, where $j$ is the imaginary unit) were carried out in the frequency range $f=10^{-2} \ldots 10^{5} \mathrm{~Hz}$. The resistivity values were calculated according to the equations: $\rho^{*}=\rho^{\prime}-j \rho^{\prime \prime}$, where $\rho^{\prime}=Z^{\prime} \cdot A / d$, and $\rho^{\prime \prime}=Z^{\prime \prime} \cdot A / d$ are the real and imaginary part of the complex resistivity based on the measured geometric parameters of the samples under research (thickness $d$ and surface area $A$ ). The complex specific electrical conductivity was calculated according to the equation from the ratio: $\sigma^{*}=$ $1 / \rho^{*}=\sigma^{\prime}+j \sigma^{\prime \prime}$, where $\sigma^{\prime}=\rho^{\prime} / M, \sigma^{\prime \prime}=\rho^{\prime \prime} / M$ are the real and imaginary parts of the complex specific electrical conductivity by parameter, $M=|Z|^{2} \cdot(A / d)$. The ratio according to which the total electrical conductivity of the materials was calculated is as follows $\sigma^{*}=$ $\left[\left(\sigma^{\prime}\right)^{2}+\left(\sigma^{\prime \prime}\right)^{2}\right]^{1 / 2}[9]$.

\section{RESULTS AND DISCUSSION}

In order to predict the prospects of using the obtained CMs as electrodes of electrochemical energy storage systems, much attention is paid to the study of structural and morphological changes that a carbon material undergoes in the process of its production, activation, or modification. A simple and accurate Raman spectroscopy (RS) method was used to identify the various phases of CM. Due to its sensitivity to changes in transsimetry, RS allows the separation of several types of carbon, such as diamond, graphite, diamond type of carbon, and carbon nitride. The Raman spectra of nanocrystalline and amorphous carbon are dominated by peaks D (D for disordered carbon) and G ( $G$ for graphite) with different intensities, positions, and bandwidths [1012]. The $\mathrm{G}$ band at about $1540-1600 \mathrm{~cm}^{-1}$ corresponds to the symmetric $\mathrm{E}_{2 g}$ mode in graphite type materials, while the $\mathrm{D}$ band at $1350 \mathrm{~cm}^{-1}$ arises from limitations in the size of the graphite domain caused by grain boundaries or defects such as $N$-substituted atoms $s p^{3}$ carbon or impurities. The peak D is absent from an ideal crystal graphite and appears only in the presence of a disordered structure. Thus, the G and D peaks are due only to the $s p^{2}$ positions for visible excitation. The $s p^{2}$ sites have a large cross section, so they dominate the spectra $\left(s p^{3}\right.$ are imperceptible), and the resulting RS corresponds only to the configuration or content of the $s p^{2}$ site. Consequently, the spectra for amorphous carbon depend on the clustering of the $s p^{2}$ phase, the bond length, the disordering of the bond angle, the presence of an $s p^{2}$ ring or chain, and the $s p^{2} / s p^{3}$ ratio. The spectra directly depend on the quality or configuration of the $s p^{2}$ phase and partly on the amount of the $s p^{2}$ phase. Most often, the $s p^{2}$ configuration changes sequentially with the $s p^{2}$ fraction [13]-[15]. Figure 2 shows the RS of the CM obtained at different carbonization temperatures.

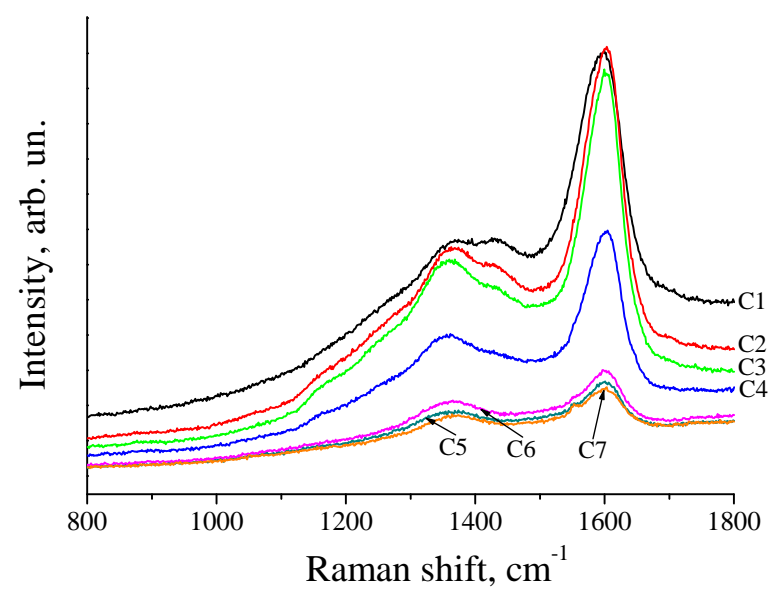

Fig. 2. The Raman spectra of the carbonated CM

The spectra are dominated by the relatively intense phonon $\mathrm{G}$ and D modes of the first order located at about $1350 \mathrm{~cm}^{-1}$ and $1600 \mathrm{~cm}^{-1}$, and are characteristic of CM. A typical linear schedule of the output spectrum for the two bands ( $\mathrm{G}$ and $\mathrm{D}$ ) is shown in Fig. 3.

The maximum intensity of the $G$ and $D$ bands changes significantly with an increase in the carbonization temperature of the feedstock. Analysis of the integrated intensities of the $\mathrm{D}$ and $\mathrm{G}$ modes allows one 
to estimate the average size of graphite fragments along the basal plane (002) of graphite [16] as $L(\mathrm{~nm})=$ $\left(2.4 \cdot 10^{-10}\right) \cdot \lambda^{4} \cdot\left(I_{\mathrm{G}} / I_{\mathrm{D}}\right)$, where $\lambda=488 \mathrm{~nm}$ is the wavelength of the laser radiation. The RS were approximated by two Lorentzians to determine the integral intensities of the D and G modes (Fig. 3). The dependence of the average size of graphite fragments on the carbonization temperature (Fig. 4) demonstrates a decrease in the average transverse particle size of graphite fragments from $9.86 \mathrm{~nm}$ to $8 \mathrm{~nm}$ during carbonization in the temperature range $400-800^{\circ} \mathrm{C}$. An increase in the carbonization temperature $\left(900^{\circ} \mathrm{C}\right.$ and $\left.1000^{\circ} \mathrm{C}\right)$ leads to the growth of graphite particles and can be explained by the process of the material sintering.

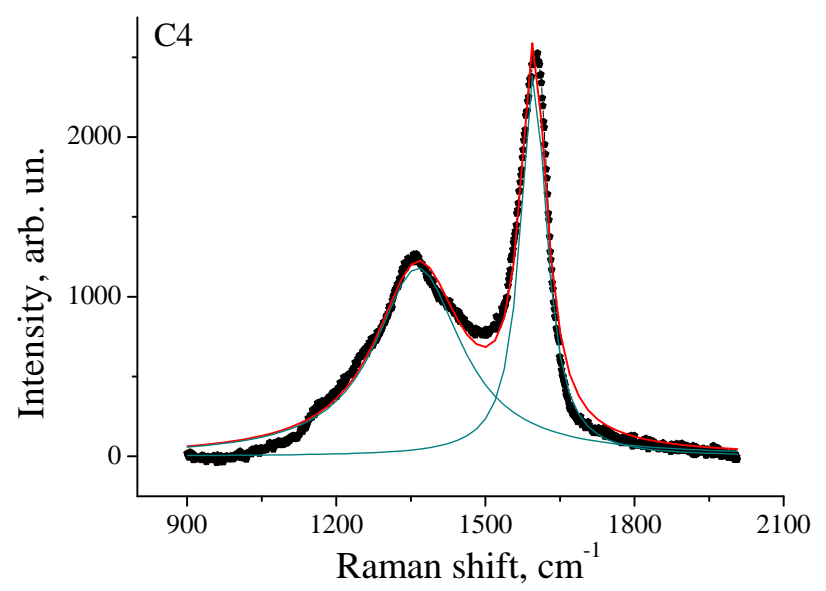

Fig. 3. Raman spectrum of the CM cut off at the temperature of carbonization of $700^{\circ} \mathrm{C}$

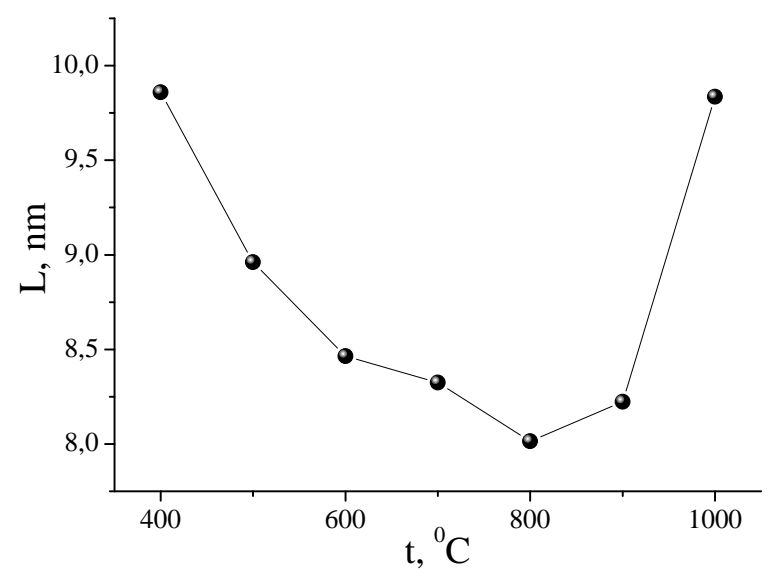

Fig. 4. Dependence of the average size of graphite fragments on the carbonization temperature of the $\mathrm{CM}$

The RSs obtained for the researched CMs are visually similar; therefore, their study was carried out in more detail. The RS was approximated using the Origin 6.1 program by five Lorentz contours (G, D1, D2, D3, D4) (Fig. 5), which are suitable for first-order spectra and give exact characteristics of the CM.

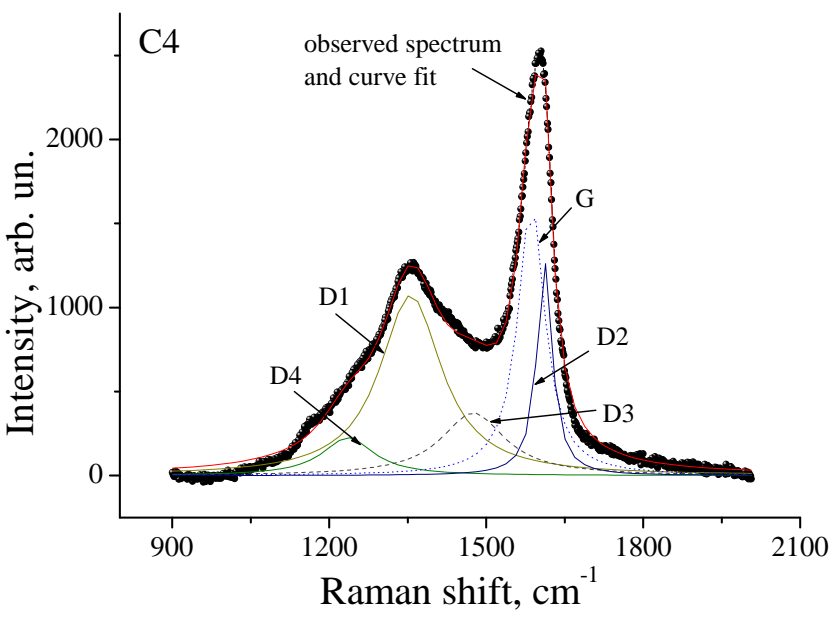

Fig. 5. Typical Raman spectrum and the result of its modeling for the $\mathrm{CM}$ obtained at a carbonization temperature of $700^{\circ} \mathrm{C}$

The following bands were identified from the analysis of the obtained spectra; $\mathrm{G}\left(\sim 1589 \mathrm{~cm}^{-1}\right)$ corresponds to an ideal graphite lattice (E2g symmetry) [17, 18]; D1 (D) $\left(\sim 1350 \mathrm{~cm}^{-1}\right)$ is a disordered graphite lattice (edges of the graphene layer, A1g symmetry) [17, 18]; D2 ( 1605 $\mathrm{cm}^{-1}$ ) is a disordered crystal lattice of graphite (surface layers of graphene, E2g symmetry), observed as a wing of the $\mathrm{G}$ mode [18]; D3 $\left(\sim 1500 \mathrm{~cm}^{-1}\right)$ is amorphous carbon $[19,20]$; D4 $\left(\sim 1200 \mathrm{~cm}^{-1}\right)$ corresponds to a disordered graphite lattice (A1g symmetry) [21], polyenes [19], ion impurities [20], etc. Using the data from the approximation of the RS, the full line width at half maximum (FWHM) and the relative and integral intensities of all curves were determined (Fig. 6). The degree of CM disordering is displayed by the width of the $\mathrm{D}$ and $\mathrm{G}$ bands at half their height. A decrease in the width of the D3 and $\mathrm{D} 4$ bands (Fig. 6a) indicates a decrease in the degree of disordering, which is observed for the CM carbonized in the range of $400-800^{\circ} \mathrm{C}$. Therefore, carbonization at $900^{\circ} \mathrm{C}$ and $1000^{\circ} \mathrm{C}$ leads to an increase in the amount of amorphous carbon and an increase in the degree of disordering of the graphite lattice. The relationship between the half-width of the intensity curves D1 and $G$ and the ratio of their integrated intensities $I_{D 1} / I_{G}$ indicates a decrease in both parameters. An increase in the $\mathrm{I}_{\mathrm{D} 1} / \mathrm{I}_{\mathrm{G}}$ value (Fig. $6 \mathrm{~b}$ ) for $\mathrm{C} 1-\mathrm{C} 5 \mathrm{CM}$ probably indicates an increase in the amorphous component due to an increase in the porous structure of the CM. The decrease in the $\mathrm{I}_{\mathrm{D} 1} / \mathrm{I}_{\mathrm{G}}$ ratio for samples $\mathrm{C} 6$ and $\mathrm{C} 7$ is probably the result of an intense graphitization process, which is logical for higher temperatures of the carbonization process. Analyzing the data obtained, it is possible to describe the evolution of the electrophysical properties of a carbon material within the framework of the following model. Thus, the CM can be thought of as a heterophase system in which graphitized particles with relatively high conductivity are dispersed in a matrix formed by porous amorphous carbon and residues of lignin and cellulose, which are characterized by much lower conductivity values. 
An increase in the carbonization temperature initiates both the burnout of a part of the amorphous component, reflected by an increase in the bulk density (Table 1 ), and the graphitization of the material. According to the Raman spectroscopy data, at temperatures below $1000^{\circ} \mathrm{C}$, a decrease in the average size of graphite crystallites is observed. This result can be explained based on the position, in the range of $400^{\circ}-900^{\circ} \mathrm{C}$, the nucleation and growth of a large number of small graphi-

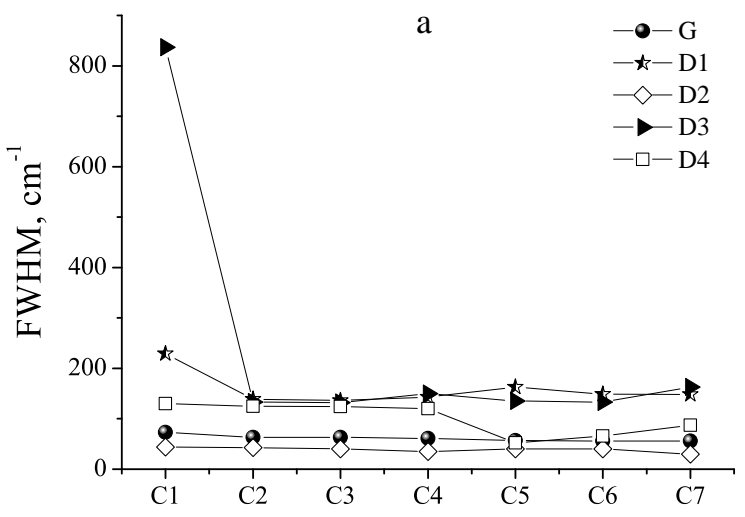

Fig. 6. The value of the full line width at half maximum FWHM te crystallites occurs throughout the entire volume of the system the material is graphitized. In this case, the dispersion of the existing crystallites cannot be expected; however, the average size value decreases. A sharp jump in linear dimensions at $1000^{\circ} \mathrm{C}$ corresponds to the phase of the graphitization process, in which the nucleation of new crystallites no longer occurs, but the growth of existing ones continues.

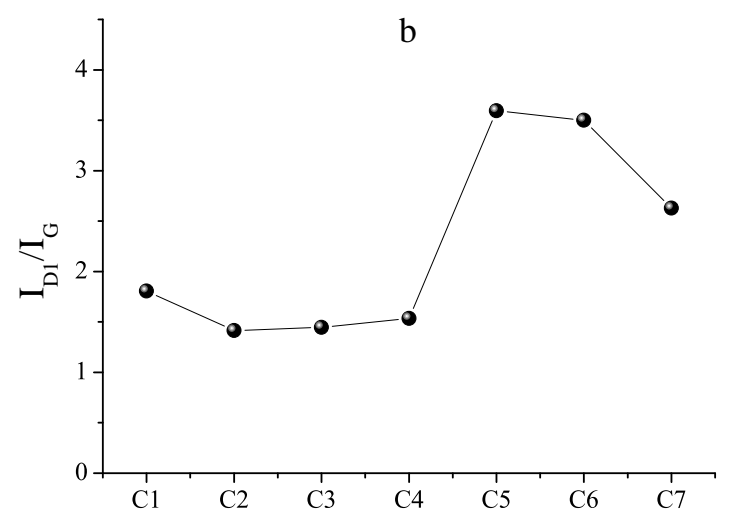

The method of FTIR spectroscopy was used for a more detailed research on the surface state of the obtained CM, identification of functional groups present on the carbon surface. Information about the carbon groups available on the CM surface will make it possible to establish the causes of changes in the physicochemical properties of the CM. The middle infrared spectrum (4000-400 $\left.\mathrm{cm}^{-1}\right)$ can be conditionally divided into four regions: the $\mathrm{XH}$ stretch region $\left(4000-2500 \mathrm{~cm}^{-1}\right)$, the triple bond region (2500-2000 $\left.\mathrm{cm}^{-1}\right)$, the double bond region (2000-1500 $\left.\mathrm{cm}^{-1}\right)$ and the area of "fingerprints" (1500-600 $\left.\mathrm{cm}^{-1}\right)$, which is characterized by the spectrum of the molecule and can have a hundred or more absorption bands [22]. Analyzing the IR spectra for samples of carbonized CM (Fig. 7), it was determined that aromatic $\mathrm{C}-\mathrm{H}$ bending peaks are observed for all samples in the range 900$600 \mathrm{~cm}^{-1}$.

For samples $\mathrm{C} 1$ and $\mathrm{C} 3$, a noticeable peak at $870 \mathrm{~cm}^{-1}$ is usually associated with the symmetric deformation of the $\mathrm{CO}_{3}$ group [23]. The presence of a peak at $1590 \mathrm{~cm}^{-1}$ in the spectra (C1 and $\mathrm{C} 3$ ) is due to the stretching mode of $\mathrm{C}=\mathrm{C}\left(s p^{2}\right)$ bonds of aromatic rings and indicates the presence of alkenes, which is accordance with the characteristic of stretching vibrations of $\mathrm{C}-\mathrm{H}$ bonds in $\mathrm{CH}_{2} / \mathrm{CH}_{3}$ groups [23]. The IR spectra for samples $\mathrm{C} 4$ and $\mathrm{C} 7$ (Fig. 7) show an absorption band at $1989 \mathrm{~cm}^{-1}$, which is associated with the Raman vibrational modes in the carbon structure. The bands at $2100 \mathrm{~cm}^{-1}$ are due to the stretching of the $\mathrm{C}=\mathrm{C}$ and $\mathrm{C}=\mathrm{O}$ bonds. Stretching carbonyl is one of the simplest absorptions that can be recognized in the infrared spectrum. Usually this is an intense band in the spectrum and depending on the type of $\mathrm{C}=\mathrm{O}$ bond $[22]$.

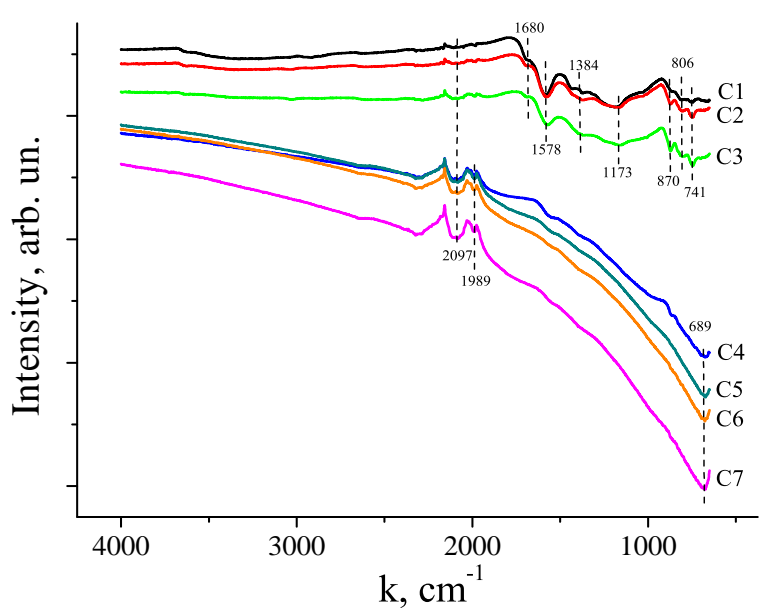

Fig. 7. IR spectra of the $\mathrm{CM}$ obtained at different temperatures of carbonization

Total impedance spectroscopy is an effective method for studying the electrophysical characteristics of various materials crystalline and disordered semiconductors, heterogeneous systems and composite structures [24]. Measuring electrical conductivity at alternating current allows one to research electrochemical and electrophysical processes in ion-conducting materials, to research the features of diffusive charge transfer in disordered systems, and to determine the parameters characterizing electronic conductivity. The frequency dependences 
of the real and imaginary parts of the impedance for porous nanomaterials are determined by the predominant mechanism of electron transport and largely depend on their stoichiometric composition and porous structure [25]. The conductivity of such materials is determined by both the bulk characteristics of carbon nanoparticles grains (deviation from stoichiometry or the presence of dopants), the state of intergrain boundaries, and porosity of the material, and can be considered as the sum of electrical conductivities, which are characterized by different mechanisms of charge transfer [26].
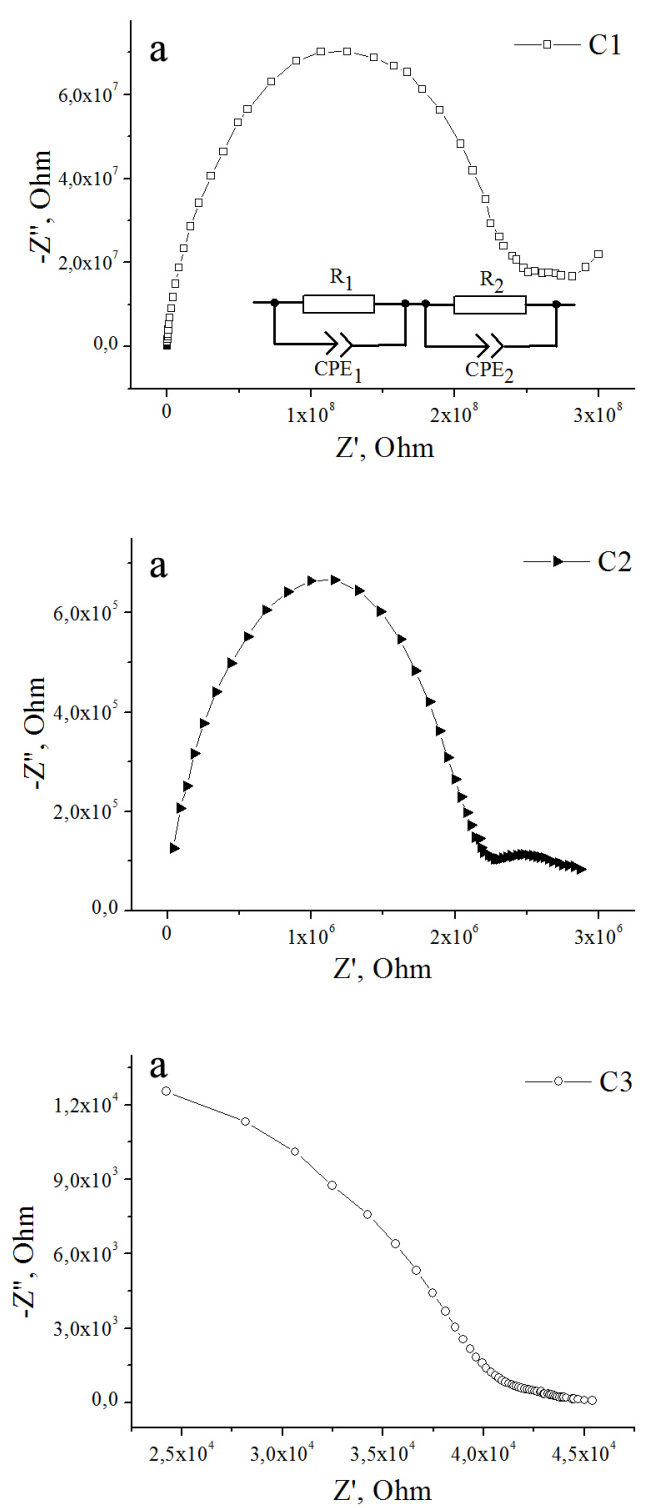

According to the results of impedance spectroscopy, the carbonization temperature of the feedstock significantly affects the electrical conductive properties of the obtained carbon material, as evidenced by the change in the form of the impedance hodograph $Z^{\prime \prime}=f\left(Z^{\prime}\right)$ (Figs. 8-10) and quantitative changes in the real $Z^{\prime}$ and imaginary $Z^{\prime \prime}$ components of the complex resistance of the system. Consequently, as a result of the research, it was found that thermal carbonization in the temperature range of $400-1000^{\circ} \mathrm{C}$ leads to a change in the values of both the real and imaginary parts of the resistance.
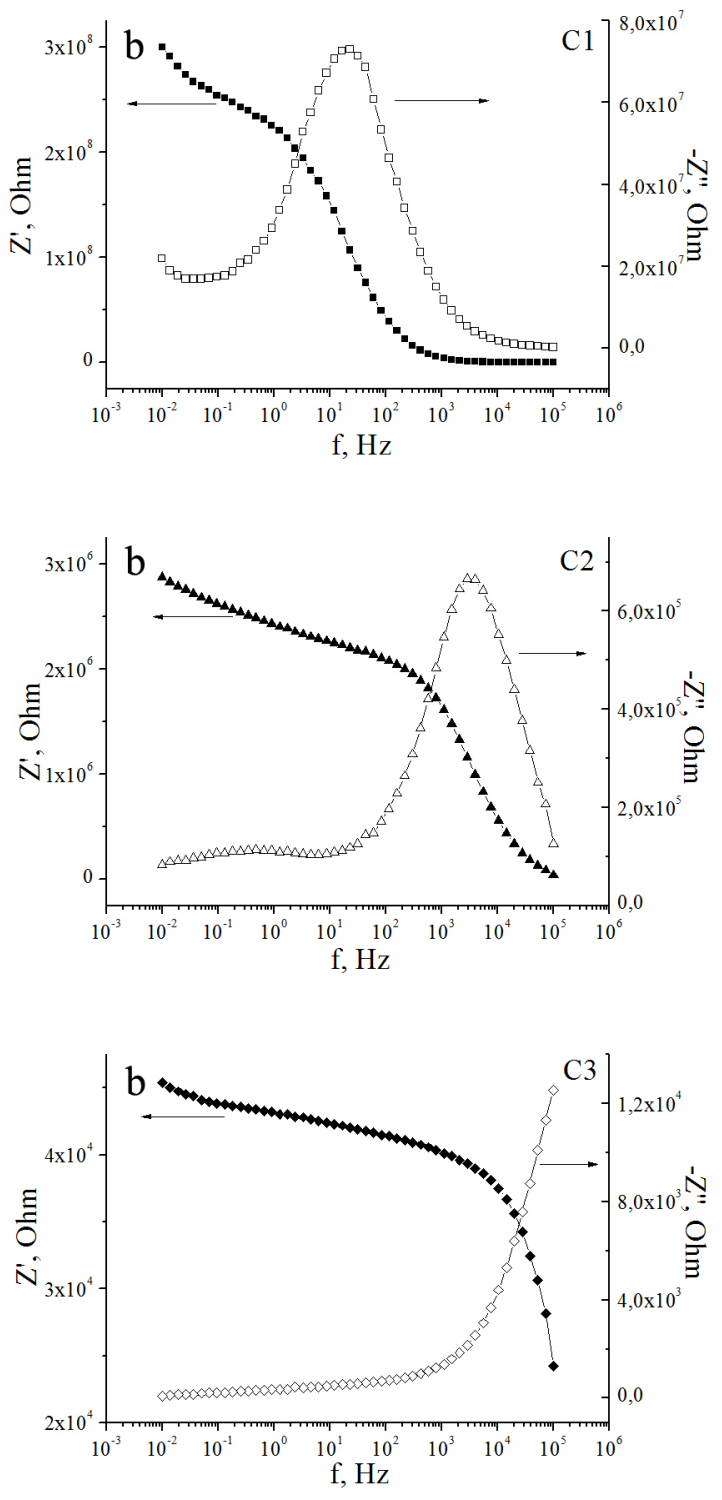

Fig. 8. The nyquist diagrams of $\mathrm{CM}$ obtained at carbonization temperatures of $400-600^{\circ} \mathrm{C}(\mathrm{a})$ and the dependence of the real $Z^{\prime}$ and imaginary $Z^{\prime \prime}$ parts of the impedance on the frequency $f$ of the alternating current (b)

The analysis of impedance hodographs within the framework of the equivalent circuit method allows one to separate the contributions to the conductivity from the volume of particles and intergrain boundaries. It should be noted that this problem is not simple due to the presence of many factors that can affect the conducti- on mechanism. Therefore, a quantitative analysis of the frequency dependence of the impedance based on the selected equivalent circuit makes it possible to interpret its elements in accordance with possible physicochemical processes in the samples when an electric current flows through them [26]. 
The frequency dependences of $Z^{\prime}(f)$ and $Z^{\prime \prime}(f)$ (Fig. 8, b) have a similar form for samples $\mathrm{C} 1-\mathrm{C} 3$. However, the values of resistance differ by two orders of magnitude. The obtained Nyquist diagrams can be modeled using the same equivalent electrical circuit (EES) (Fig. 8, a tab). The EES used to approximate the experimental impedance spectra for carbon samples C1-C3 (inset in Fig. 8, a - C1) includes a series of lowfrequency $\left(\mathrm{R}_{1}-\mathrm{CPE} \mathrm{E}_{1}\right.$ circuit $)$ and high-frequency $\left(\mathrm{R}_{2}-\right.$ $\mathrm{CPE}_{2}$ circuit) links, in which the resistor $\mathrm{R}$ and constant phase element CPE are connected in parallel. Probably the low-frequency $\mathrm{R}_{1}-\mathrm{CPE}_{1}$ circuit corresponds to the processes of charge carrier transfer across the grain boundaries: $\mathrm{CPE}_{1}$ is a capacitive-type constant phase element, $\mathrm{R}_{1}$ includes the resistance of the lead wires and contacts between the copper electrodes of the cell and the CM and carbon particles in the bulk of the material. This assumption is confirmed by a decrease in $R_{1}$ with an increase in the temperature of the carbonizati- on process of the feedstock, since in the range of 400$600^{\circ} \mathrm{C}$ the thermal decomposition of organic feedstock does not occur to the full extent, and the resulting carbon material contains resin residues that prevent good contact between carbon particles. It was determine that probably at low carbonization temperatures $\left(\leq 600^{\circ} \mathrm{C}\right)$ the formation of a complex carbon framework is not yet complete [27]. The high-frequency circuit $R_{2}-\mathrm{CPE}_{2}$ can correspond to the conductivity of the volume of carbon particles: $\mathrm{CPE}_{2}$ is a capacitive type constant phase element that takes into account the porous (or fractal) structure of the carbon material, $R_{2}$ is the resistance of the carbon matrix [26]. The resistance values can be obtained from the points of intersection of the semicircle with the Z'axis, and the capacitance value from the equation for the maximum frequency value $\omega_{\max } \mathrm{RC}=1$. The values of the EC parameters for all samples are given in Table 2 .

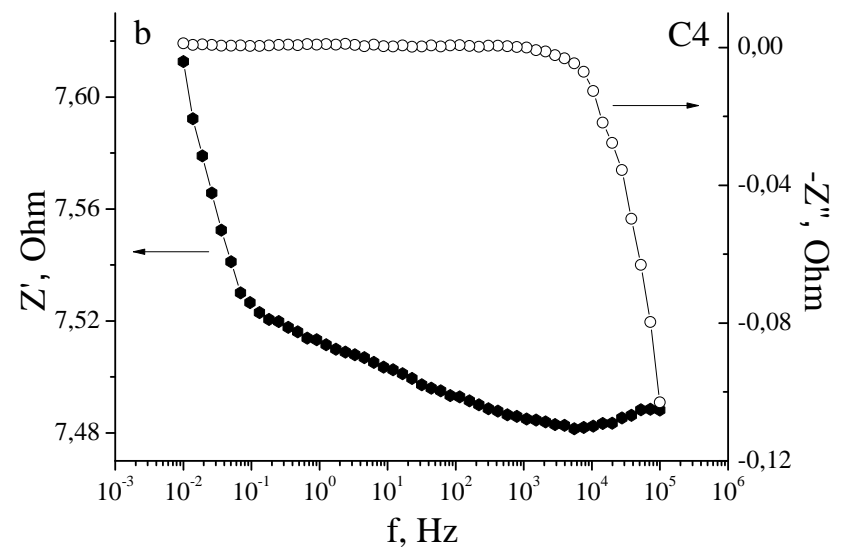

Fig. 9. The nyquist diagram of the $\mathrm{CM}$ obtained at $700^{\circ} \mathrm{C}$ (a) and the dependence of the real $Z^{\prime}$ and imaginary $Z^{\prime \prime}$ parts of the impedance on the frequency $f(b)$
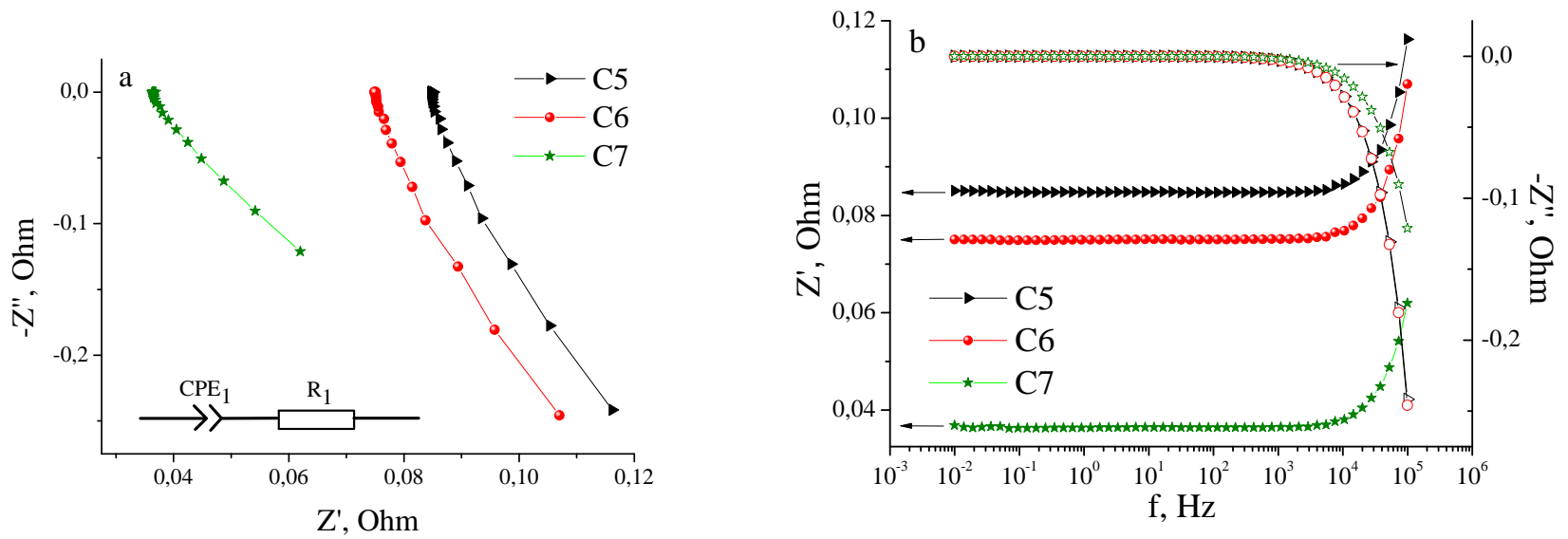

Fig. 10. The nyquist diagrams of the $\mathrm{CM}$ obtained at $800-1000^{\circ} \mathrm{C}$ (a) and the dependence of the real $Z^{\prime}$ and imaginary $Z^{\prime \prime}$ parts of the impedance on the frequency $f(b)$ 


\begin{tabular}{|l|c|c|c|c|c|c|c|c|}
\hline Parameter & $\mathrm{C} 1$ & $\mathrm{C} 2$ & $\mathrm{C} 3$ & $\mathrm{C} 4$ & $\mathrm{C} 5$ & $\mathrm{C} 6$ & $\mathrm{C} 7$ \\
\hline $\mathrm{R}_{1}$ & & $2.4 \mathrm{E} 8$ & $2.2 \mathrm{E} 6$ & $4.0 \mathrm{E} 4$ & 7.474 & 0.085 & 0.075 & 0.036 \\
\hline $\mathrm{R}_{2}$ & & $3.8 \mathrm{E} 7$ & $4.0 \mathrm{E} 5$ & $3.0 \mathrm{E} 3$ & - & - & - & - \\
\hline $\mathrm{CPE}_{1}$ & $\mathrm{~A}$ & $6 \mathrm{E}-13$ & $5 \mathrm{E}-10$ & $1 \mathrm{E}-9$ & $1.35 \mathrm{E} 6$ & $1.30 \mathrm{E} 6$ & $1.29 \mathrm{E} 6$ & $1.50 \mathrm{E} 6$ \\
\hline & $\mathrm{n}$ & 0.8 & 0.7 & 0.73 & -0.9 & -0.95 & -0.98 & -0.91 \\
\hline $\mathrm{CPE}_{2}$ & $\mathrm{~A}$ & $4 \mathrm{E}-7$ & $4 \mathrm{E}-6$ & $5 \mathrm{E}-5$ & 15 & - & - & - \\
\hline & $\mathrm{n}$ & 1 & 0.6 & 0.4 & 0.2 & - & - & - \\
\hline
\end{tabular}

Table 2. The values of parameters of the equivalent circuit elements for $\mathrm{C} 1-\mathrm{C} 7$ samples

The frequency dependences of the real and imaginary parts of the impedance undergo significant changes with an increase in the temperature of the carbonization process from 400 to $700^{\circ} \mathrm{C}$ (Fig. 8, b and Fig. 9, b). On the one hand, there is a significant decrease in the values of $Z^{\prime}$ and $Z^{\prime \prime}$ (more than $7 \div 9$ orders of magnitude). On the other hand, the dependences $Z^{\prime \prime}(f)$ exhibit a "plateau" and a region of rapid decline in the value of $Z^{\prime}$ (Fig. 8, b and Fig. 9, b), which undergo displacements with an increase in the carbonization temperature from $400^{\circ} \mathrm{C}$ to $700^{\circ} \mathrm{C}$ (samples $\mathrm{C} 1$ and $\mathrm{C} 4$ ). Accordingly, a maximum is observed on the $Z^{\prime \prime}(f)$ dependences, which also shifts towards high frequencies and passes into the region lying outside the measuring range. There is a transition of the value of the imaginary resistance from the negative half-plane to the positive. For the $\mathrm{CM}$ which was obtained at $700-1000^{\circ} \mathrm{C}$, we observed the predominance of the inductive component of the system over the capacitive one in the frequency range $10^{5} \div 800 \mathrm{~Hz}$ (Fig. 9, b and Fig. 10, b samples $\mathrm{C} 4-\mathrm{C} 7$ ).

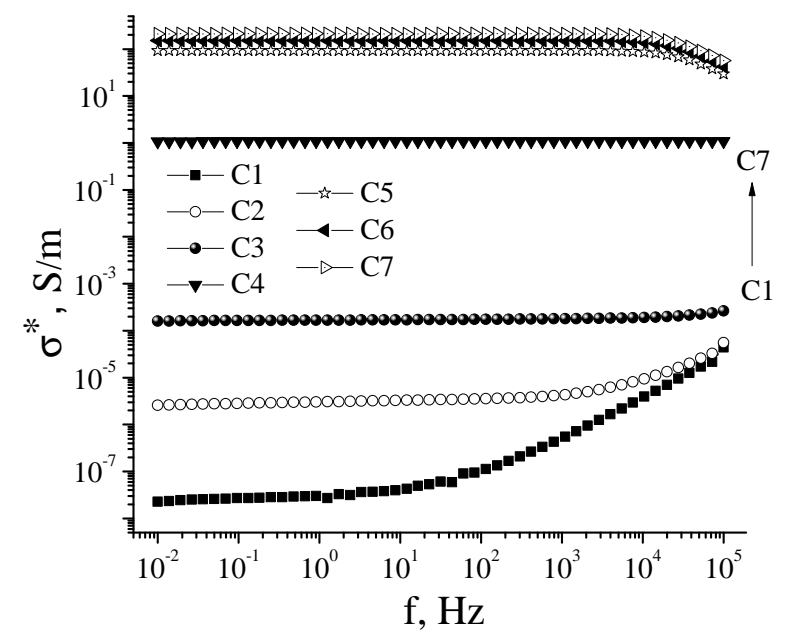

Fig. 11. Frequency dependence of the specific electrical conductivity of $\mathrm{CM}$

The equivalent circuit used to approximate the experimental spectrum of sample $\mathrm{C} 4$ (Fig. 9, a tab) includes a series-connected low-frequency element of the DC phase inductive type $\mathrm{CPE}_{1}$, resistor $R_{1}$ and highfrequency $\mathrm{CPE}_{2}$ capacitive type. For samples $\mathrm{C} 5-\mathrm{C} 7$, the impedance modeling is also reduced to one scheme, but different from the EES obtained for samples $\mathrm{C} 1-\mathrm{C} 3$ and sample C4 (Fig. 10, a - tab).
In the EES for samples $\mathrm{C} 5-\mathrm{C} 7$, there is no highfrequency constant phase element of the capacitive type $\mathrm{CPE}_{2}$. The values of the EEC parameters are given in Table 2. Figure $10 \mathrm{~b}$ shows the low-frequency sections where the dependence of both the real and imaginary parts of the impedance on the frequency of the alternating current is not observed for samples $\mathrm{C} 5-\mathrm{C} 7$. An increase in the value of $Z^{\prime}$, which is accompanied by a decrease in the imaginary part of the impedance $Z^{\prime \prime}$, occurs in the high-frequency region $\left(10^{3} \div 10^{5} \mathrm{~Hz}\right)$. At the same time, the value of the apparent resistance for materials $\mathrm{C} 5-\mathrm{C} 7$ is unchanged and is equal to about $4.4 \cdot 10^{-5} \mathrm{Ohm}$ in the low frequency range (Fig. 10).

The real, imaginary, and full conductivity of the CM were calculated based on the above relations. Figure 11 shows the dependence of the total conductivity $\sigma^{*}$ on the frequency. Moreover, the figure shows that for all materials in the frequency range $10^{-3} \div 10^{3} \mathrm{~Hz}$, the value of $\sigma^{*}$ is independent of frequency. Thus, the specific conductivity of the CM increases sharply with an increase in frequency at carbonization temperatures below $700^{\circ} \mathrm{C}$ (Fig. 11). At the same time, its decline occurs in the frequency range $10^{3} \div 10^{5} \mathrm{~Hz}$ at carbonization temperatures of $700-1000^{\circ} \mathrm{C}$. Such frequency dependence is insufficiently studied. There are several explanations in the literature: a possible dispersion of electrical conductivity in the region $\mathrm{f} \leq 10^{5} \mathrm{~Hz}$ due to the skin effect or under the condition $\omega \sim 1 / \tau$, where $\tau$ is the relaxation time; due to the occurrence of collective excitations of the wave type of charge density in fine systems [28].

The flow of electric current in such a system can be adequately described within the framework of the percolation theory. Thus, each point of the material with a probability $\psi$, which will be determined by the carbonization temperature, corresponds to the conductivity of the graphite component $\sigma_{\mathrm{g}}$, and with a probability $1-\psi$ is the conductivity of the amorphous component of $\sigma_{\mathrm{am}}$. The current flow threshold in this case will be determined by the statistical spatial distribution of the graphite component $\sigma_{\mathrm{g}}$. At small values of $p$, graphite clusters are isolated from each other. Therefore, due to an increase in the carbonization temperature, the probability of contact between graphite clusters increases, and at the threshold temperature $t_{\mathrm{cr}}$, the conductivity of the system sharply increases. The concept of the proposed model is close solving the problem of determining the dependence of the conductivity of the composite "carbon structures in a polymer matrix" on the concentration of the leading component [29]. 
In general, the conductivity of such a system is related to the percolation threshold $\theta_{\mathrm{cr}}$ (the value of the concentration of the leading component at which an infinite cluster with a conductivity is formed in the system, which is much higher than the conductivity of the matrix) and the concentration of the leading component according to the power law $\sigma=\sigma_{\mathrm{g}}\left(\theta-\theta_{\mathrm{cr}}\right)^{p}$, where $p$ is the critical index depending on the dimension of the system [30]. In our case, the value of $\theta$ is proportional to the carbonization temperature $t$, therefore, the equation is rewritten in the form $\sigma=A \sigma_{\mathrm{g}}\left(t-t_{\mathrm{cr}}\right)^{p}$, where $t_{\text {cr }}$ is the carbonization temperature at which an infinite leading cluster is formed in the system, and $A$ is a constant. To determine the parameters of the percolation threshold and the critical index $p$, the procedure for constructing and linearizing the dependence is typically used $\ln (\sigma)=f\left(\ln \left[\theta-\theta_{\mathrm{cr}}\right]\right)$, which provides for the selection of the value of $\theta_{c r}$ and allows finding the parameter $p$ as the slope of the obtained function. We propose a scheme for finding $t_{\mathrm{cr}}$ as the inflection point of the functional dependence of the conductivity of the carbon material on the carbonization temperature. It should be noted that the introduction of percolation conductivity in the case under study will depend not only on the carbonization temperature, but also on the frequency of the electric field applied to the material carbonized at a certain temperature. Thus, we analyzed the dependences of the total conductivity of the material on the carbonization temperature at eight selected frequencies in the range $0.01-10^{5} \mathrm{~Hz}$ (Fig. 12, a).
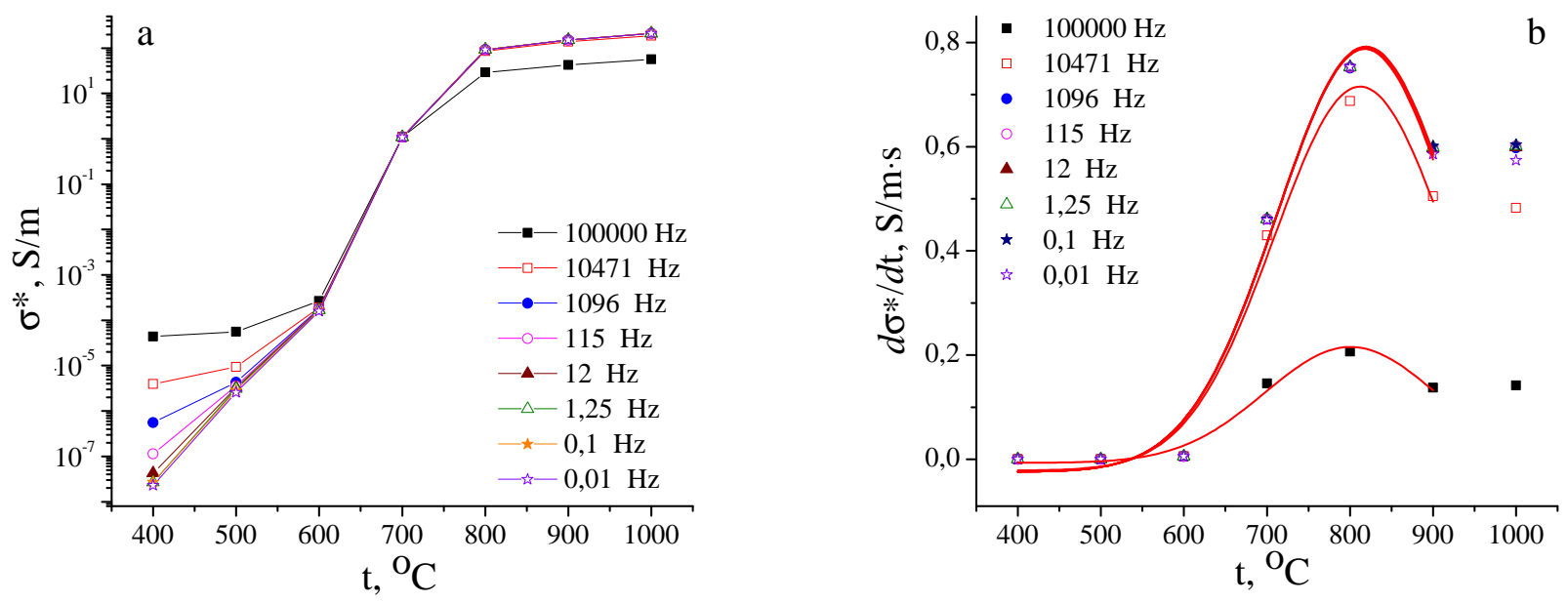

Fig. 12. Dependences of the CM conductivity (a) and the dependence of the first derivative of conductivity (b) on the carbonization temperature at the selected frequencies

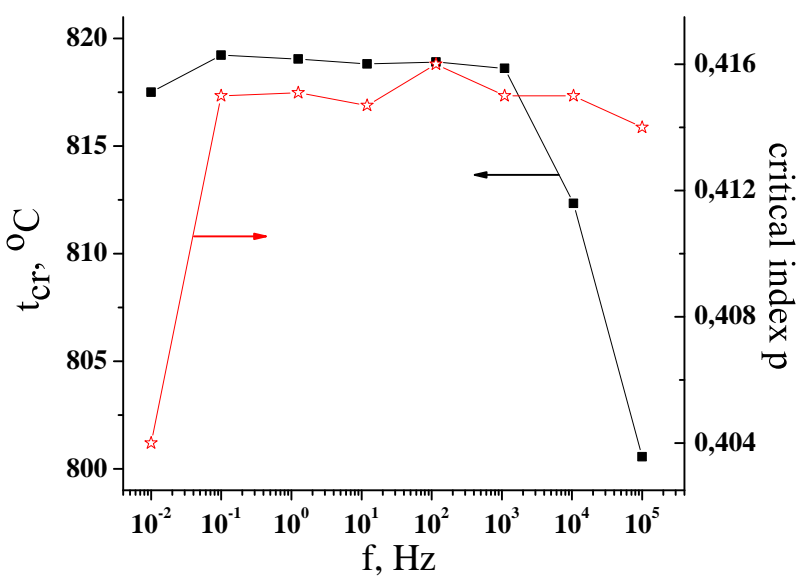

Fig. 13. Frequency dependences of percolation threshold $t_{\mathrm{cr}}$ and critical index $p$ for the $\mathrm{CM}$

The inflection point was found from the position of the maximum of the dependence of the first derivative $d \sigma / d t$ as a function of the carbonization temperature with the application to this dependence of the approxi- mation by Gaussian functions (Fig. 12, b). According to the results obtained, the value of the percolation threshold $t_{\mathrm{cr}}$ lies in the range $800-817^{\circ} \mathrm{C}$, and an increase in the frequency of the electric field causes a decrease in $t_{\text {cr }}$ (Fig. 13). This dependence is expected, since the probability of electron tunneling between the particles of the leading carbon component, as one of the components of the percolation conductivity mechanism, increases with an increase in the frequency of the external field [31].

The frequency dependence of the critical index was determined based on the statement about the existence of a linear relationship between $\ln (\sigma)$ and $\ln \left[t-t_{\mathrm{cr}}\right]$ (Fig.13). It was determined that the value of the exponent $p$ in the investigated frequency range is close to 0.415 (only at a frequency of $0.01 \mathrm{~Hz}$ there is a sharp drop to 0.404 ). The obtained result is somewhat unexpected, since in most cases the value of $p$ is greater than 1 , but the good reproducibility of the value obtained at different frequencies allows confirming the reliability of the experimental data obtained. At the same time, according to [32], for the case of composites based on carbon nanotubes, the values of the critical index were close to 0.7 . 


\section{CONCLUSIONS}

On the one hand, the temperature in the process of carbonization of the raw material makes an impact on the structure and condition of the surface of the obtained carbon material. On the other hand, it leads to a change in its conductive properties. It was found that in the Raman spectra for all investigated samples of $\mathrm{CM}$ phonon $\mathrm{D}$ and $\mathrm{G}$ bands are observed, which correspond to $\mathrm{A} 1 \mathrm{~g}$ and $\mathrm{E} 2 \mathrm{~g}$ oscillatory modes of carbon atoms with a $s p^{2}$ type of chemical bond, respectively. It was determined that the ratio of the integrated intensities $\mathrm{I}_{\mathrm{D} 1} / \mathrm{I}_{\mathrm{G}}$ of $\mathrm{CM}$ which was obtained at a temperature of $\leq 700^{\circ} \mathrm{C}$ is two to three times lower than for the samples, whose carbonization temperature is $800-1000^{\circ} \mathrm{C}$, which is also indicated by the increase in the electrical conductivity of the C5 and C7 samples. The presence of additional D3 and $\mathrm{D} 4$ bands in all samples of the carbon material indicates the presence of amorphous carbon and disordered graphite layers.

The model of the structure evolution with an increase in the carbonization temperature was created based on the application of the theory of percolation to the analysis of the frequency dependences of the conductivity of the obtained carbon materials. It was determined that the investigated carbon nanomaterials can be described as systems in which graphitized particles are dispersed in a dielectric matrix. At the same time, the formation of graphitization centers in the heat treatment temperature range of $400-900^{\circ} \mathrm{C}$ is observed by Raman spectroscopy as a decrease in the relative sizes of graphite crystallites. In this case, the percolation threshold corresponds to the carbonization temperature at which an infinite leading cluster is formed in the material, formed by contacting graphitized carbon particles. Thus, an increase in the frequency of the electric field in the range of 0.01 to $10^{5} \mathrm{~Hz}$ causes a shift in the percolation threshold from 817 to $800^{\circ} \mathrm{C}$, which suggests the presence of a mechanism for electron tunneling between graphitized particles. The calculated values of the critical percolation index are weakly dependent on frequency and lie in the range from 0.404 to 0.415 .

Acknowledgment. This work was supported by the National Research Foundation of Ukraine (project 2020.02/0043).
[1] M. Salanne et al., Nat. Energy 1, 16070 (2016); https: //doi .org/10.1038/nenergy. 2016.70.

[2] W. He et al., Adv. Energy Mat. 7, 1700983 (2017); http s://doi.org/10.1002/aenm. 201700983.

[3] B. K. Ostafiychuk, I. M. Budzulyak, M. M. Kuzyshyn, R. P. Lisovskiy, V. I. Mandzyuk, J. Nano- Electr. Phys. 5, 03049 (2013).

[4] B. E. Conway, J. Electrochem. Soc. 138, 1539 (1991).

[5] B. I. Rachiy, B. K. Ostafiychuk, I. M. Budzulyak, N. Y. Ivanichok, J. Nano- Electron. Phys. 7, 04077 (2015).

[6] L. Jiang et al., Carbon 111, 207 (2017); https://doi. org/10.1016/j . carbon. 2016.09.081.

[7] J. Wang, S. Kaskel, J. Mat. Chem. 22, 23710 (2012); https://doi.org/10.1039/C2JM34066F.

[8] B. K. Ostafiychuk et al., J. Nano- Electr. Phys. 11, 03036 (2019); https://doi.org/10.21272/jnep.11(3) .03036 .

[9] M. H. Abdullah, A. N. Yusoff, J. Alloys Compd. 233, 129 (1996); https://doi.org/10.1016/0925-8388(96 ) $80044-2$.

[10] A. C. Ferrari, J. Robertson, Phys. Rev. B 61, 14095 (2000); https://doi.org/10.1103/PhysRevB.6 1.14095 .

[11] A. C. Ferrari, Diam. Rel. Mat. 11, 1053 (2002); https: //doi.org/10.1016/S0925-9635(01) 00730-0.

[12] J. Filik, P. W. May, S. R. J. Pearce, R. K. Wild, K. R. Hallam, Diam. Rel. Mat. 12, 974 (2003); https: //doi.org/10.1016/S0925-9635(02) 00374-6.

[13] J. Li et al., Appl. Surf. Sci. 191, 273 (2002); https: //doi.org/10.1016/S0169-4332(02)00221-0.

[14] J. R. Shi et al., Diam. Rel. Mat. 10, 76 (2001); https: //doi.org/10.1016/S0925-9635(00) 00403-9.

[15] R. Hauert et al., Thin Solid Films 268, 22 (1995); https : //doi .org/10.1016/0040-6090 (95) 06824-4.

[16] M. A. Pimenta et al., Phys. Chem. Phys. 9, 1276 (2007); https://doi.org/10.1039/B613962K

[17] F. Tuinstra, J. L. Koenig, J. Chem. Phys. 53, 1126 (1970); https://doi.org/10.1063/1.1674108.

[18] Y. Wang, D. C. Alsmeyer, R. L. McCreery, Chem. Mater. 2, 557 (1990); https://doi.org/10.1021/cm00011a018.

[19] B. Dippel, J. Heintzenberg, J. Aerosol. Sci. 30, 907 (1999); https://doi.org/10.1016/S0021-8502(99) 804 64-9.

[20] A. Cuesta, P. Dhamelincourt, J. Laureyns, A. MartinezAlonso, J. M. D. Tascon, Carbon 32, 1523 (1994); http s://doi.org/10.1016/0008-6223(94) 90148-1.

[21] R. Al-Jishi, G. Dresselhaus, Phys. Rev. B 26, 4514 (1982); https://doi.org/10.1103/PhysRevB.26.4514.

[22] B. H. Stuart, Infrared Spectroscopy: Fundamentals and Applications (John Wiley \& Sons, Ltd, 2004); https: //doi.org/10.1002/0470011149.

[23] A. Galvez, M. Herlin-Boime, C. Reynaud, C. Clinard, J. N. Rouzaud, Carbon 40, 2775 (2002); https://doi . org/10.1016/S0008-6223(02) 00195-1.

[24] E. Barsoukov, J. Macdonald, Impedance Spectroscopy: Theory, Experiment, and Applications, Second Edition (John Wiley \& Sons, Ltd, 2005); https://doi.org/10 .1002/0471716243.

[25] I. M. Budzulyak et al., Phys. Chem. Solid State 21, 409 (2020); https://doi.org/10.15330/pcss.21.3.4 $09-414$.

[26] I. I. Grigorchak, G. V. Ponedilok, Impedance Spectroscopy (Lviv Polytechnic National University Publishing House, Lviv, 2011).

[27] B. K. Ostafiychuk et al., Nanosistemi, Nanomater. Nanotehnologii 16, 303 (2018).

[28] D. Starešinić, K. Biljaković, N. I. Baklanov, S. V. Zaitsev- 
Zotov, Ferroelectrics 176, 335 (1996); https://doi.or $\mathrm{g} / 10.1080 / 00150199608223621$.

[29] A. Motaghi, A. Hrymak, G. H. Motlagh, J. Appl. Polymer Sci. 132, 41744 (2015); https://doi.org/10 $.1002 /$ app. 41744 .

[30] W. Bauhofer, J. Z. Kovacs, Compos. Sci. Technol. 69, 1486 (2009); https://doi.org/10.1016/j.compscitec h.2008.06.018.
[31] Y. Wang, G. J. Weng, S. A. Meguid, A. M. Hamouda, J. Appl. Phys. 115, 193706 (2014); https://doi.org/ 10.1063/1.4878195.

[32] M. R. Mansor, S. H. S. M. Fadzullah, N. A. B. Masripan, G. Omar, M. Z. Akop, Functionalized Graphene Nanocomposites and their Derivatives (Elsevier, 2019); https://doi.org/10.1016/B978-0-12-814548-7.000 $09-\mathrm{X}$.

\title{
ВПЛИВ ТЕМПЕРАТУРИ КАРБОНІЗАЦІї РОСЛИННОЇ ЫІОМАСИ НА СТРУКТУРУ, СТАН ПОВЕРХНІ Й ЕЛЕКТРОПРОВІДНІ ВЛАСТИВОСТІ ВУГЛЕЦЕВОГО НАНОПОРИСТОГО МАТЕРІАЛУ
}

\author{
Н. Я. Іванічок, О. М. Іванічок, Б. І. Рачій, П. І. Колковський, І. М. Будзуляк, В. О. Коцюбинський, \\ В. М. Бойчук, Л. 3. Хрущ \\ Прикарпатсъкий начіоналъний університет імені Василя Стефаника, \\ вул. Шевченка, 57, м. Івано-Франківсък, 76000, Украӥна
}

Щоб спрогнозувати перспективи застосування нанопористих вуглецевих матеріалів як електродів електрохімічних систем накопичення енергії, вивчено структурно-морфологічні зміни, яких зазнає вуглецевий матеріал під час його отримання. Описано простий метод термічної карбонізації для одержання вуглецевого нанопористого матеріалу (ВНМ) зі шкаралупи волоських горіхів. Наведено результати дослідження впливу температури карбонізації вихідної сировини на електропровідні властивості отриманих вуглецевих матеріалів. Показано, що температура процесу карбонізації впливає не тільки на структуру та стан поверхні цього вуглецевого матеріалу, але й спричиняє зміну його електропровідності.

Методом раманівської спектроскопії досліджено фазовий склад отриманих ВНМ. Показано, що на спектрах наявні чіткі фононні D- i G-смуги для всіх зразків BHM, які відповідають A1g та E2g коливним модам атомів вуглецю з $s p^{2}$-типом хімічного зв'язку. Також у всіх одержаних вуглецевих матеріалах наявні додаткові D3- і D4 -смуги, які вказують на наявність розупорядкованих шарів графіту та аморфного вуглецю. Підвищення температури карбонізації вихідної сировини суттєво змінює максимум інтенсивності G- і D-смуг. Аналіз інтегральних інтенсивностей D- та G- смуг дав змогу оцінити середній розмір графітових фрагментів.

Для вивчення стану поверхні отриманих ВНM, а саме, для ідентифікації наявних на поверхні вуглецю функціональних груп, застосовано метод інфрачервоної фур'є-спектроскопії. Інформація про наявні на поверхні ВНМ вуглецеві групи дала змогу встановити причини зміни фізико-хімічних властивостей вуглецевого матеріалу.

Досліджували електропровідні властивості ВНМ методом імпедансної спектроскопії в діапазоні частот від $10^{-2}$ до $10^{5}$ Гц. Для інтерпретації спектрів імпедансу всіх зразків використовували діаграми Найквіста. Проаналізовано зміну електропровідності як функцію температури карбонізації вихідної сировини. У праці розраховано значення питомих опорів, комплексну та повну питому електропровідність матеріалів. Застосування теорії перколяції до аналізу частотних залежностей провідності отриманих вуглецевих матеріалів дозволило побудувати модель еволюції їхньої структури з підвищенням температури карбонізації.

Ключові слова: вуглецевий нанопористий матеріал, питома електропровідність, імпедансна спектроскопія, Раманівська спектроскопія, ІЧ-спектроскопія. 